\title{
Trip attraction model of central market in Poso City based on multiple linier regression model
}

\author{
Henny Indriyani Abulebu ${ }^{1, *}$, BleiserTanari ${ }^{1}$ and Muhammad Isran Ramli ${ }^{2}$ \\ ${ }^{1}$ Sintuwu Maroso University, Department of Civil Engineering, Poso, Indonesia \\ ${ }^{2}$ Hasanuddin University, Civil Engineering Department, Gowa, Indonesia.
}

\begin{abstract}
Analysis of trip attraction in shopping centers is one of the most important aspects of travel demand management (TDM) in developing countries. This research aims to describe significant factors that influence people in obtaining their choice of frequency. Variables used in this research are family's socio-demographic variables, properties of trip to shopping centers, nature of selecting trip time, and ways to travel. This research adopts multinomial logit model by modeling or building causal relationship between significant variables that influence trip frequency. The findings show that on holiday, no variable has significant influence towards the trip attraction of visitor movement at the Poso Central Market, while on workday, shopping cost (X16) has become the most influential variable. Based on the regression equation, the trip attraction of visitor movement model at the Poso Central Market on holiday is $\mathrm{Y}=2.076+$ $0.997 \mathrm{X} 6+0.276 \mathrm{X} 13+0.605 \mathrm{X} 15+0.643 \mathrm{X} 16$, where $\mathrm{R}^{2}=0.004$ below $5 \%$ or tend to close to 0 , so it can be concluded that the ability of independent variables in explaining variation of variables is very limited. Meanwhile, the regression equation on the trip attraction of visitor movement model at the Poso Central Market on workday is $\mathrm{Y}=3.090+$ $0.250 \mathrm{X} 2+0.158 \mathrm{X} 6+0.628 \mathrm{X} 15+0.050 \mathrm{X} 16+0.662 \mathrm{X} 17$, where $\mathrm{R}^{2}=$ 0.030 below $5 \%$ or tend to approach to close to 0 , so it can be concluded that the ability of independent variables in in explaining variation of variables is also very limited.
\end{abstract}

\section{Introduction}

Of all variety of human activities, one of them is trip to fulfill the needs of the economy, such as shopping trip. The human needs for shopping is very important to fulfill since this plays an important role in fulfilling human being's daily needs, thus enabling high frequencies of trip to a shopping center. Recently, shopping trip has received a wide focus of researchers' attention. Shopping trip has big proportion for urban trips, especially during peak period. The journey has more individual temporal

\footnotetext{
* Corresponding author: henny_indriyani@yahoo.co.id
} 
flexibility than travel journeys and provides more congestion and some types of environmental problems in the downtown zone [1].

Trip needs are fundamental in traffic planning. The key is how much effort is needed to meet the travel demand what method should be used. Among all factors that influence the selection of modes, the dominant factors in working is time factor. The next dominant factor is cost, and then safety, and the last factor is convenient factor $[2$, $3]$.

The function of travel-time constraint is more dominant than the function of mileage constraint and trip cost in the modeling process of transportation needs. Mode is a means used to travel. Models of mode selection aims to determine proportion of people who will use each mode. Socio-economic condition and pattern of traveler's activities is a major factor affecting traveler's decision. Before predicting transportation demand, it is necessary to determine the factors of traveler's decision, in this case how customers' behavior can be used to predict their decision in choosing transportation service. Decisions made by travel agents also greatly determine quantity, distribution of modes and routes, and time of transportation means in the transportation network as well [4-6].

Through the analysis of travel demand management (TDM), it is found that several key aspects have become people's interest to solve problems that arise; such is key aspects in four trip models (i.e. trip awakening, trip attraction, trip frequency, and others). For trip frequency, people who come to shopping places consider many factors for their trip (mall or traditional market), not only for one particular place but also for destination of shopping trip.

From various existing shopping centers in Poso, the researchers chose Poso Central Market as the research object. Formerly, this market was located at the center of Poso City, but then has been located in suburban area of Poso City. This relocation also influences the movement behaviors of travelers. This research is expected to generate model of trip frequency that can be used to determine the route for public transportation of the city.

\section{Desk study}

The researchers used questionnaire as technique of data collection. The data collection activities were done in Poso Central Market, where the number of respondents was obtained after a survey was conducted to find out the number of visitors entering the market zone. The sampling procedure was divided into workday and holiday, where the samples for workday were obtained on Tuesday, February 2017 and for holiday were on Saturday, February 18, 2017.

\subsection{Determining Sample Size}

In this research, sample size was determined based on the population size of mode transportation service users. The researchers used Slovin's formula [7], which is as follows: 


$$
n=\frac{N}{1+N d^{2}}
$$

Where:

$\mathrm{n}=$ number of samples

$\mathrm{d}=$ error tolerance

$\mathrm{N} \quad=$ total population

Sample size was determined based on the population number, which was the number of visitors on workday and holiday. Error tolerance for sample size was 0.05 or $95 \%$ for each population number. Table 1 shows the sample size for this research.

Table 1. Sample Size

\begin{tabular}{|c|c|c|c|}
\hline No & Day & Number of visitor & Sample size \\
\hline 1 & Workday & 7708 & 381 \\
\hline 2 & Holiday & 9001 & 383 \\
\hline
\end{tabular}

\subsection{Data Display and Analysis Method}

Several statistical tests were used to analyze the data, as explained below:

\subsubsection{Validity and Reliability Test}

Questionnaire validity and reliability test were used to ensure that questionnaires used in this research can really measure research variables. An instrument is considered as valid if it can measure what is supposed to measure and reveal data from the examined variables.

\subsubsection{Correlation Analysis}

Correlation test was used to test the strength of a relationship between independent and dependent variables, and between independent variables.

\subsubsection{Regression Analysis}

The largest number was chosen to represent all independent variables with correlation value greater than 0.5 . Later, all chosen variables were used to yield equation model.

\section{Findings and Discussions}

\subsection{Visitors Distribution}


Based on the survey of market visitors conducted on workday and holiday, the distribution of market visitor frequency in time period of 15 minutes with 10 hours of time intensity can be seen in Figure 1 and 2.

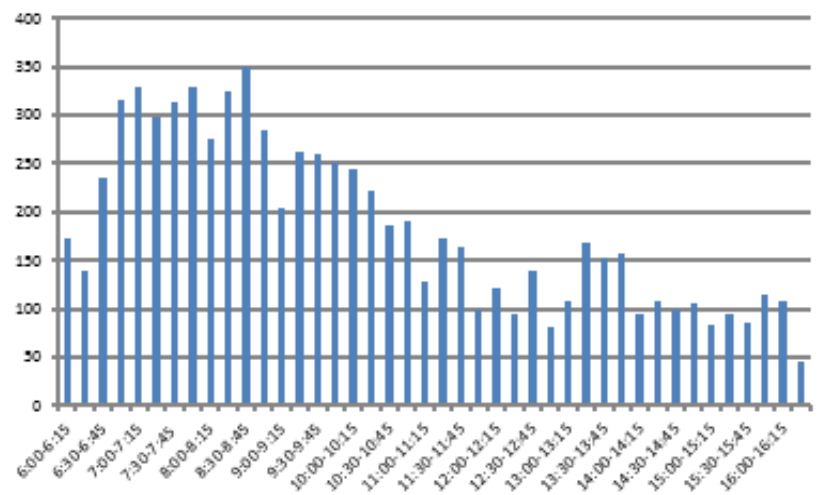

Fig. 1. Distribution Graph of Visitors on Workday

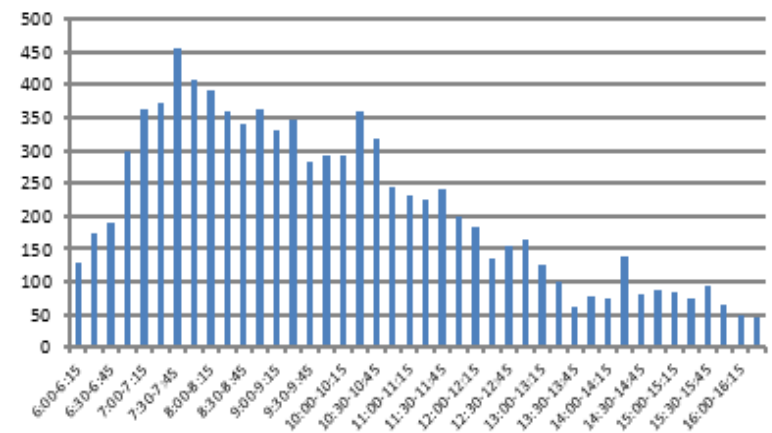

Fig. 2. Distribution Graph of Visitors on Holiday

\subsection{Model of trip attraction calculation}

The data obtained from questionnaire were analyzed by multiple regression through SPSS 16 software. The model of trip attraction formulation was later generated by regression analysis with the following steps:

\subsection{Validity and reliability test}

$\mathrm{R}$ table value can be seen in $\mathrm{R}$ table, where $\mathrm{df}=$ number of sample -2 , or in this case $\mathrm{df}$ $=383-2=381$. From significance level $5 \%, R$ table value $=0,10085$. The results obtained after analyzing samples for holiday showed that variable X2, X6, X13, X14, X15, and X16 were reliable and valid.

Table 2. Result of Validity and Reliability Test for Holiday

\begin{tabular}{|c|c|c|c|c|}
\hline No & $\begin{array}{c}\text { Parameter } \\
\text { Model }\end{array}$ & Variable & $\begin{array}{c}\text { r- } \\
\text { count }\end{array}$ & Conclusion \\
\hline
\end{tabular}




\begin{tabular}{|l|l|l|l|c|}
\hline 1 & X1 & Age & 0.084 & Not valid \\
2 & X2 & Number of people at home & 0.127 & Valid \\
3 & X3 & Number of working people & 0.035 & Not valid \\
4 & X4 & Number of people at school age & 0.072 & Not valid \\
5 & X5 & Job & -0.019 & Not valid \\
6 & X6 & Income & 0.155 & Valid \\
7 & X7 & Number of car & -0.108 & Not valid \\
8 & X8 & Number of motorcycle & 0.068 & Not valid \\
9 & X9 & Car license ownership & 0.072 & Not valid \\
10 & X10 & Motorcycle license ownership & -0.016 & Not valid \\
11 & X11 & Transportation to market & -0.196 & Not valid \\
12 & X12 & Number of companion to market & -0.021 & Not valid \\
13 & X13 & Distance from house to market & 0.197 & Valid \\
14 & X14 & Transportation cost to market & 0.146 & Valid \\
15 & X15 & Time needed from house to market & 0.129 & Valid \\
16 & X16 & Shopping expense & 0.255 & Valid \\
17 & X17 & Shopping duration & 0.070 & Not valid \\
\hline
\end{tabular}

$R$ table value can be seen in $R$ table, where $d f=$ number of sample -2 , or in this case $\mathrm{df}$ $=381-2=379$. From significance level $5 \%, \mathrm{R}$ table value $=0,10115$. The results obtained after analyzing samples for workday showed that variable X2, X6, X13, X15, X16, and X17 were reliable and valid.

Table 3. Result of Validity and Reliability Test for Workday

\begin{tabular}{|c|c|l|c|c|}
\hline No & $\begin{array}{c}\text { Parameter } \\
\text { Model }\end{array}$ & $\begin{array}{c}\text { r- } \\
\text { count }\end{array}$ & Conclusion \\
\hline 1 & X1 & Age & -0.042 & Not valid \\
2 & X2 & Number of people at home & 0.194 & Valid \\
3 & X3 & Number of working people & -0.036 & Not valid \\
4 & X4 & Number of people at school age & 0.043 & Not valid \\
5 & X5 & Job & 0.003 & Not valid \\
6 & X6 & Income & 0.192 & Valid \\
7 & X7 & Number of car & -0.002 & Not valid \\
8 & X8 & Number of motorcycle & -0.019 & Not valid \\
9 & X9 & Car license ownership & 0.041 & Not valid \\
10 & X10 & Motorcycle license ownership & 0.092 & Not valid \\
11 & X11 & Transportation to market & -0.026 & Not valid \\
12 & X12 & Number of companion to market & -0.080 & Not valid \\
13 & X13 & Distance from house to market & 0.154 & Valid \\
14 & X14 & Transportation cost to market & 0.049 & Not valid \\
15 & X15 & Time needed from house to market & 0.167 & Valid \\
16 & X16 & Shopping expense & 0.309 & Valid \\
17 & X17 & Shopping duration & 0.184 & Valid \\
\hline
\end{tabular}

\subsection{Correlation analysis for variables}

After performing normality test for each variable, correlation analysis was conducted to analyze the correlation between all independent variables $(\mathrm{X})$ and correlation between dependent variable $(Y)$ with independent variables $(X)$, where the dependent variable (Y) was the intensity of shopping day.

Table 4. Matrix of Correlation between Variables on Holiday

\begin{tabular}{|l|l|l|l|l|l|l|l|}
\hline Variable & Y & X2 & X6 & X13 & X14 & X15 & X16 \\
\hline
\end{tabular}




\begin{tabular}{|c|c|c|c|c|c|c|c|}
\hline $\mathrm{Y}$ & 1 & - & - & - & - & - & - \\
\hline $\mathrm{X} 2$ & 0.436 & 1 & - & - & - & - & - \\
\hline $\mathrm{X} 6$ & 0.866 & 0.900 & 1 & - & - & - & - \\
\hline $\mathrm{X} 13$ & 0.339 & 0.460 & 0.001 & 1 & - & - & - \\
\hline $\mathrm{X} 14$ & 0.241 & 0.783 & 0.109 & 0 & 1 & - & - \\
\hline $\mathrm{X} 15$ & 0.812 & 0.927 & 0.142 & 0 & 0 & 1 & - \\
\hline $\mathrm{X} 16$ & 0.656 & 0.379 & 0.011 & 0.109 & 0 & 0.017 & 1 \\
\hline
\end{tabular}

Table 5. Matrix of Correlation between Variables on Workday

\begin{tabular}{|c|c|c|c|c|c|c|c|}
\hline Variable & Y & X2 & X6 & X13 & X15 & X16 & X17 \\
\hline $\mathrm{Y}$ & 1 & - & - & - & - & - & - \\
\hline $\mathrm{X} 2$ & 0.089 & 1 & - & - & - & - & - \\
\hline $\mathrm{X} 6$ & 0.033 & 0.011 & 1 & - & - & - & - \\
\hline $\mathrm{X} 13$ & 0.025 & 0.919 & 0.334 & 1 & - & - & - \\
\hline $\mathrm{X} 15$ & 0.275 & 0.727 & 0.248 & 0 & 1 & - & - \\
\hline $\mathrm{X} 16$ & 0.006 & 0.001 & 0 & 0 & 0 & 1 & - \\
\hline $\mathrm{X} 17$ & 0.500 & 0.028 & 0.456 & 0.019 & 0 & 0 & 1 \\
\hline
\end{tabular}

Table 4 shows the systematic analysis procedure. Under the existing conditions, independent variables had to be lesser than $>0.5$. From Table 4 , it is shown that independent variables X2 and X15 had high correlation coefficient, so the relationship between these two variables were quite strong. Based on the terms, only one variable can be used in the model, so the researchers chose variable X15 since this variable had higher correlation coefficient than variable X2 on Y as dependent variable. Similarly, all variable with correlation coefficient lesser than $>0.5$ were chosen in this model, which were X6, X13, X16 and X15.

Table 5 shows the systematic analysis procedure. Similar to the test previously performed, independent variables had to be lesser than > 0.5. From Table 5, independent variables X2 and X13 had high correlation coefficient, so the relationship between these two variables were quite strong. Variable $\mathrm{X} 2$ was chosen since this variable had higher correlation coefficient than variable $\mathrm{X} 13$ on $\mathrm{Y}$ as dependent variable. Variables used in the model were X2, X6, X15, X16 and X17.

\subsection{Regression model analysis of market visitor attraction}

All variables that passed correlation test were later analyzed by regression analysis in order to get the best model.

Table 6. Results of Modeling Visitor Movement Attraction on Holiday

\begin{tabular}{|c|c|c|c|c|c|}
\hline \multirow[t]{2}{*}{ Model } & \multicolumn{2}{|c|}{$\begin{array}{c}\text { Unstandardized } \\
\text { Coefficients }\end{array}$} & \multirow{2}{*}{\begin{tabular}{|c|}
$\begin{array}{c}\text { Standardized } \\
\text { Coefficients }\end{array}$ \\
Beta
\end{tabular}} & \multirow[t]{2}{*}{$\mathbf{T}$} & \multirow[t]{2}{*}{ Sig. } \\
\hline & B & $\begin{array}{l}\text { Std. } \\
\text { Error }\end{array}$ & & & \\
\hline $1 \quad$ (Constant) & 2.076 & .263 & & 7.890 & .000 \\
\hline Income & .000 & .031 & .000 & .004 & .997 \\
\hline Distance from house to market & -.054 & .049 & -.060 & -1.087 & .278 \\
\hline
\end{tabular}




\begin{tabular}{l|l|l|l|r|r|}
\hline Time needed from house to market & .015 & .029 & .028 & .517 & .605 \\
Shopping expense & .013 & .028 & .024 & .464 & .643 \\
\hline
\end{tabular}

Before reading the results of each variable's effect, we have to make sure whether those variables had significant effect on $\mathrm{Y}$ or not, by checking the $t$ value and significance value of each variable. If we use $t$ value, it is said to be significant if $t$ value is greater than $t$ table, while if we use significance value, it is said that the variable is significant if sig value is lesser than a (in this case, the value $=5 \%$ ). We can see in the table that no variables had significant effect on dependent variable.

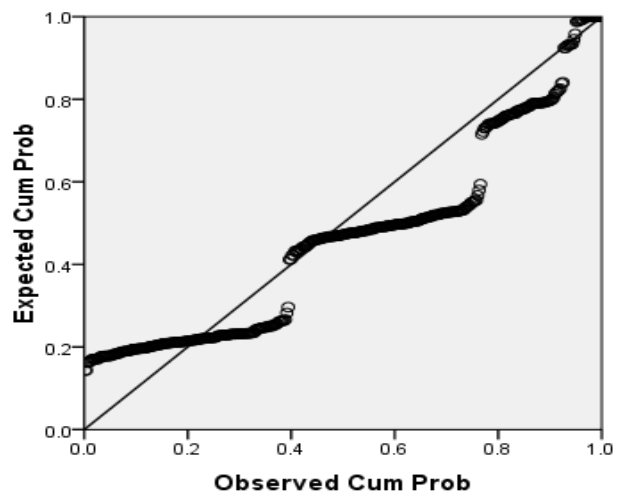

Fig 3. Graph of Normality Test for Holiday

Figure 3 shows the graph model for normality test performed with SPSS, where the existing points spread around diagonal line despite the extreme point, and its distribution follows the direction of diagonal line. Based on the independent variables, this regression model can then be used to predict the amount of trip attraction to the market on workday.

Table 7. Results of Modeling Visitor Movement Attraction on Workday

\begin{tabular}{|c|c|c|c|c|c|c|}
\hline \multirow{2}{*}{\multicolumn{2}{|c|}{ Model }} & \multicolumn{2}{|c|}{$\begin{array}{c}\text { Unstandardized } \\
\text { Coefficients } \\
\end{array}$} & \multirow{2}{*}{\begin{tabular}{|c|}
$\begin{array}{c}\text { Standardized } \\
\text { Coefficients }\end{array}$ \\
Beta \\
\end{tabular}} & \multirow[t]{2}{*}{$\mathbf{T}$} & \multirow[t]{2}{*}{ Sig. } \\
\hline & & B & $\begin{array}{l}\text { Std. } \\
\text { Error }\end{array}$ & & & \\
\hline \multirow[t]{6}{*}{1} & (Constant) & 3.090 & .420 & & 7.351 & .000 \\
\hline & Number of people at home & .087 & .075 & .060 & 1.152 & .250 \\
\hline & Income & .084 & .060 & .074 & 1.416 & .158 \\
\hline & Time needed from house to market & .026 & .053 & .027 & .485 & .628 \\
\hline & Shopping expense & .082 & .042 & .113 & 1.968 & .050 \\
\hline & Shopping time & -.039 & .088 & -.025 & -.437 & .662 \\
\hline
\end{tabular}

Similar to the previous procedure, we have to make sure whether those variables had significant effect on $\mathrm{Y}$ or not, by checking the $\mathrm{t}$ value and significance value of each variable. If we use $t$ value, it is said to be significant if $t$ value is greater than $t$ table, 
while if we use significance value, it is said that the variable is significant if sig value is lesser than a (in this case, the a value $=5 \%$ ). We can see in the table that variable X16 had significant effect on dependent variable.

Figure 4 shows the graph model for normality test performed with SPSS, where the existing points spread around diagonal line despite the extreme point, and its distribution follows the direction of diagonal line. Based on the independent variables, this regression model can then be used to predict the amount of trip attraction to the

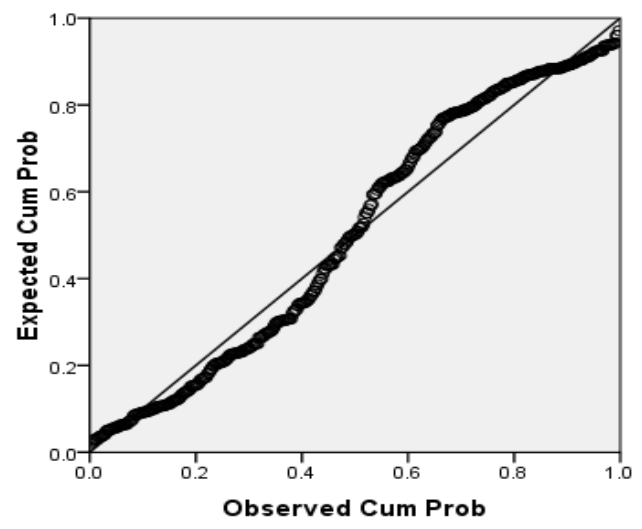

market on holiday.

Fig 4. Graph of Normality Test for Workday

\section{Conclusions}

Based on the analysis results, no factors had significant effect on the trip attraction of Poso Central Market visitors on workday, while shopping expense (X16) had significant effect on the trip attraction on holiday. From the regression equation, model of trip attraction for visitor movement to Poso Central Market on holiday was $\mathrm{Y}=2.076+$ $0.997 \mathrm{X} 6+0.276 \mathrm{X} 13+0.605 \mathrm{X} 15+0.643 \mathrm{X} 16$, where $\mathrm{R}^{2}=0.004$ below $5 \%$ or tends to close to 0 , therefore it is concluded that the ability of independent variables in explaining variable variation is very limited. Meanwhile, based on the regression equation, trip attraction for visitor movement to Poso Central Market on workday was $\mathrm{Y}=3.090+0.250 \mathrm{X} 2+0.158 \mathrm{X} 6+0.628 \mathrm{X} 15+0.050 \mathrm{X} 16+0.662 \mathrm{X} 17$, where $\mathrm{R}^{2}=0.030$ below $5 \%$ or tend to close to 0 . Therefore, it can be concluded that the ability of independent variables in explaining variable variation is very limited as well.

\section{References}

1. Ramli, M.I. et al. Accommodating flexible daily temporal constraint on a continuous choice model of departure time for urban shopping travel. International Journal of Urban Sciences Vol.15, No 3 .London. (2011) 
2. Setiowati, B. dkk. Studi Komparasi Pemilihan Moda Kereta Api Eksekutif dan Pesawat Terbang (Studi Kasus: Asal Semarang Tujuan Jakarta). Simposium FSTPT 6 UNHAS. No. Jurnal 77. Makassar. (2003)

3. Kurniadi, A. dkk 2000: Studi Pemilihan Metoda Trip Assignment Untuk Pemodelan Kebutuhan Transportasi Kotamadya Surabaya. Simposium FSTPT 3. Yogyakarta. (2000)

4. Asri, A dan Hamid Aly, S. Pemilihan Moda Bus dan MPU Untuk Trayek MakassarMajene. Simposium FSTPT XIII. No Jurnal 74. Semarang. (2010)

5. Magribi, L. Model Pemilihan Moda Angkutan Laut dan Penyebrangan Suatu Aplikasi Stated Preference Untuk Studi Kasus Rute Kendari-Raha di Sultra. (2003)

6. Wicaksono, S.: Analisa Faktor-Faktor yang Mempengaruhi Pemilihan Moda Transportasi Penduduk Kerja di Kecamatan Sukmajaya Depok Menuju Tempat Kerja Dengan Menggunakan Metode Analitic Hierarchy Process. Skripsi, Jurusan Teknik Sipil Fakultas Teknik Sipil dan Perencanaan, Universitas Gunadarma, Jakarta. (2008)

7. Iskandar, dkk Pemilihan Moda Antar Bus dan MPU untuk Trayek Makassar-Palopo. Simposium FSTPT XIII. No Jurnal 14. Semarang. (2010) 